\title{
Internationalization Process of Fast Fashion Retailers: Evidence of H\&M and Zara
}

\author{
Ziying $\mathrm{Mo}^{1}$ \\ ${ }^{1}$ School of Business, Macau University of Science and Technology, Avenida Wai Long, Taipa, Macau, China \\ Correspondence: Mo Ziying, School of Business, Macau University of Science and Technology, Avenida Wai \\ Long, Taipa, Macau, China. E-mail: ziying_mo@163.com
}

Received: December 16, 2014

Accepted: January 12, 2015

Online Published: February 27, 2015

doi:10.5539/ijbm.v10n3p217

URL: http://dx.doi.org/10.5539/ijbm.v10n3p217

\begin{abstract}
The fashion apparel industry has evolved significantly over the last two decades driven by the internationalisation and rapid rise of global fast fashion retailer brands. This research seeks to introduce and explore how two internationalization models-Incremental and Rapid Internationalization-can be applied to two representative global fast fashion retailers (Zara and H\&M). It seeks to apply these models on the basis of three perspectives-"knowledge sharing, resource-based view and psychic distance". The result suggested that H\&M and Zara do not entirely correlate with the expectations of Incremental and Rapid Internationalization Models. This appears to be significantly different from what has been covered in the literature, which concludes that Zara was a born-global fast fashion retailer and H\&M was a traditional/gradual global one. Another conclusion is the adoption of the Rapid Internationalization Models by the two fast fashion retailers were not completely independently from use of the Incremental Models, especially in their early expansion stages.
\end{abstract}

Keywords: incremental internationalization, rapid internationalization, global fast fashion retailers

\section{Introduction}

Over the last two decades, the fashion apparel industry has evolved significantly with many retailers undertaking worldwide expansion of their operations (Bhardwaj \& Fairhurst, 2010). This predominant trend has resulted from changing dynamics in the fashion industry, such as the fading of mass production, modified structural characteristics in the supply chain, demand for lower cost, and flexibility in design, logistics, and distribution (Doyle et al., 2006). Therefore, in order to maintain a competitive position in this increasingly dynamic market, some fashion retailers have adopted a "Quick Response" concept (Franks, 2000). According to Taplin (1999), such a strategy can be characterized as gaining competitive advantages through reducing time gaps between designing and consumption on a seasonal basis.

Based on the concept of "Quick Response", "fast fashion" has been defined as "a business strategy that aims to shrink the processes involved in the buying cycle and lead times for getting new fashion products into stores, in order to satisfy consumer demand at its peak" (Barnes \& Lea-Greenwood, 2006, p. 259). The business concept of these retailers such as Zara, Benetton and H\&M, is characterized by three components: short production and distribution lead times (quick response production capabilities); highly fashionable product design (enhanced product design capabilities); and affordable prices for the middle market-between "Prada-Primark" segments (cost control capabilities) (Cachon \& Swinney, 2011; Tokatli, 2008).

Another important reason for the changing dynamics of the fashion industry is the internationalization process of fast fashion retailers (Bhardwaj \& Fairhurst, 2010). The first step to the internationalization of many fashion retailers is often through their buying decisions, enabling the modified structural characteristics in the supply chain. One leading debate is where to source products (domestic versus offshore sourcing) and whether to manage the process of end-to-end supply chain coordination internally or to outsource part or all of the logistics functions (Fernie \& Perry, 2011).

On the other hand, the drivers of change in the fashion industry were mainly the rapid rise of global fast fashion retailer brands and their internationalization (Fernie \& Perry, 2011). Those US and European entrants to the fashion market, such as Zara, Benetton and H\&M, stretched their brands into new segments through bringing affordable style to the high street. More significantly they also took their retail concepts across the globe to grasp 
growth opportunities, and thus contributed critically to the success of the fast fashion retailers. For instance, compared to Gap with net sales of $38 \%$ coming from its international activities, Zara and H\&M have a greater global presence with 79\%and 94\% respectively of net sales in 2011 (The Gap, 2011; Inditex, 2011a; H\&M, 2011a). Therefore, it is necessary to discuss the global fast fashion retail internationalization process on the basis of their retail concepts, the extent and timing of internationalization of a firm.

Efforts to study retail internationalization have been numerous with much of the existing academic literature on this area focusing on retail operations including "motives for internationalization, direction of growth, method of market entry, and degree of adaptation to new markets" (Alexander, 1997; Sternquist, 1998). Others have tended to develop retail internationalization models in relation to the Incremental Internationalization Models (Johanson \& Vahlne, 1975; 1977) by comparing another new paradigm-Rapid Internationalization Models to rethink the belief that all firms entered foreign markets gradually (Chetty \& Campbell-Hunt, 2004). However, there is limited research trying to adopt these two retail internationalization models to analyze global fast fashion retailers "internationalization process".

Therefore, the purpose of this research will be regarded mainly explorative in order to introduce and discuss how two internationalization models-Incremental and Rapid Internationalization - can be applied within global fast fashion retailers. One of the major missions is to adopt those theories as a "tool" and to translate them into the reality of two chosen global fast fashion retailers (Zara and H\&M). The review of the academic literature will assess two internationalization models-Incremental and Rapid-and then the existing literature studying this sector will also be reviewed for two fast fashion retailers: H\&M and Zara. And then, a qualitative research approach will be outlined incorporating a case study research design and data collection method. Data about H\&M's and Zara's retail concepts (design, manufacturing, logistics, and store management) and internationalization processes (International Presence, Entry Modes, International Marketing, and International Management) will be analyzed. Discussion will adopt Incremental Internationalization Models to assess how the internationalization process of H\&M aligns with this model. It will also apply the Rapid Internationalization Models to Zara.

\section{Theory}

\subsection{Incremental Internationalization Models}

The Incremental Internationalization approach is based on behavioral theoretical perspectives of the firm (Cyert \& March, 1963) and adopts a more dynamic approach that views internationalization as an incremental process. In other words, companies tart transaction activities in their domestic markets and then sequentially expand to new countries. Incremental Internationalization Models suggest firms internationalize by following predictable stages from simple steps to complex operations, entailing as low step-by-step process (Johanson \& Vahlne, 1977; $\mathrm{Li}$ et al., 2004). While many models exist to explain these characteristics of the internationalization process of the firm, one main model can be identified within this incremental approach, referred to as the "Uppsala Internationalization Model (U-Model)" by Johanson and Wiedersheim-Paul (1975); Johanson and Vahlne (1977).

The Uppsala Internationalization Model (U-Model) consisted of two sub-models: the Establishment Chain by Johanson and Wiedersheim-Paul (1975) and the Internationalization Process Model by Johanson and Vahlne $(1977 ; 1990)$, which explains two patterns of internationalization at the operational level. Firstly, firms enter into a specific market according to the establishment chain (Johanson \& Wiedersheim, 1975), which indicates an increasing commitment of resources to the market. The second pattern implies that firms enter new markets with successively greater psychic distance (e.g., psychological distance: differences in language, education, business practices, culture and industrial development) (Andersen, 1993; Johanson \& Vahlne, 1990). This suggests firms enter a particular market close to and similar to the home country before expanding into more distant and dissimilar markets.

The practical application of Incremental Internationalization Models and in particular Uppsala Internationalization Model, have been examined in many studies. In retailing there is some evidence to support this incremental approach, companies such as Gap, Aldi, Body Shop and other category companies such as IKEA and Toys ' $R$ ' Us still aligned with an "organic growth strategy" associated with the U-Model, which are willing to build up market penetration in new markets over a long time frame through developing their own sites (Helfferich et al., 1997).

Nevertheless, Incremental Internationalization has received criticism for many aspects in their models. Most of the criticism is based on the observation that company behaviour has changed due to increasing global competition and accelerated technological development. For example, stages in the Establishment Chain could be leapfrogged by some companies (Hedlund \& Kverneland, 1985). Some start-ups attempt to internationalize soon after their establishments (Oviatt \& McDougall, 1994). The internationalization process has also become 
more rapidly nowadays (Oviatt \& McDougall, 1994; Zahra et al., 2000) and the correlation between the order in which a company enters foreign markets and psychic distance has weakened (Madsen \& Servais, 1997). Consider Logitech, a global leader in computer peripherals, was established by entrepreneurs from Switzerland and the U.S., where the firms set up dual headquarters. It started the internationalization process from inception through its first commercial contract with a Japanese company (McDougall et al., 1994). Furthermore, research and development (R\&D) and manufacturing were initially split between these two countries, and then quickly spread to Ireland and Taiwan through FDI without a strong established domestic orientation (Rothaermelet al., 2006).

What is currently being debated is "slow Internationalizers" versus "Born Global Start-Ups" (Loane et al., 2007; Sapienza et al., 2006), including: can firms internationalize faster than what has been suggested by traditional stage models? Furthermore, should they rapidly internationalize? Advocates argue that every industry has become "global" and that firms need to rapidly go after these opportunities (Govindarajan \& Gupta, 2001), while incremental internationalization theories suggest that firms need to enter culturally and institutionally close markets first, spend enough time there to accumulate overseas experience, and then gradually move from more primitive modes such as exports to more sophisticated strategies such as FDI in distant markets. Consistent with Incremental Internationalization Models, Sweden's IKEA, for example, waited 20 years before entering neighbouring Norway. Only more recently has it accelerated its internationalization (Kling \& Goteman, 2003).

On the other hand, a key issue is whether it is better for firms to start the internationalization process soon after founding (i.e., Born-global firms) or to postpone until the firm has accumulated significant resources (e.g., IKEA). One view supports rapid internationalization (Autio et al., 2000). Specifically, firms following the prescription of Incremental Internationalization Models, when eventually internationalizing, must overcome substantial inertia because of their domestic orientation. In contrast, firms that internationalize earlier may overcome fewer of these barriers. Therefore, firms without an established domestic orientation (e.g., Logitech) may outperform their rivals that wait longer to internationalize (Mathews \& Zander, 2007; Nadkarni \& Perez, 2007).

Therefore, due to this deficiency of Incremental Internationalization Models, "Rapid Internationalization Models" need to be introduced and discussed to explain the internationalization process more completely.

\subsection{Rapid Internationalization Models}

Rapid Internationalization Models emerged due to the evidence that many firms avoided incremental patterns in their internationalization process and claims that they start their international activities from birth (Bell, 1995; Jones \& Dimitratos, 2004; McDougall et al., 1994; Oviatt \& McDougall, 1994). Some empirical evidence conforms to this claim which challenges the validity of Incremental Internationalization Models, in particular Uppsala Model (Bell \& McNaughton, 2000; Crick \& Jones, 2000). However, companies adopt this Rapid Internationalization Models due to new external conditions such as advances in technology regarding production, transportation and communication (Chetty \& Campbell-Hunt, 2004), and due to entrepreneurs with more international experience and foreign market knowledge (Madsen \& Servais, 1997). Furthermore, the liberalization of trade also pushes firms' customers to international markets and causes more intense competition derived from imports in its domestic market. These changing environmental conditions are creating the ideal context for Rapid Internationalization Models to emerge (Oviatt \& McDougall, 1995; 2000).

A similar approach can be found in Rennie (1993), where firms adopting Rapid Internationalization Models are labelled as Born-globals. The global economy, the increasing demand for globally customised products, growth of international value chains and global networks, offshoring and advances in technologies have contributed to the emergence of Born-globals (Knight \& Cavusgil, 1996; Madsen et al., 2000). According to Madsen and Servais (1997), successful Born-globals depend on ambition and the motivation of the founders, corporate governance, the structure of the organisation, market internationalization, innovative technology and product design. Although the Born-globals may have limited experience in international business, they offer niche products targeted at global markets and possess knowledge-intensive skills which enable them to provide value-added products and services (Gabrielsson \& Alobaidi, 2004).

\subsection{Fast Fashion Retail Internationalization}

Based on the existing literature on theories of internationalization and the emerging concept of born-global retailers, Bhardwaj et al. (2011) and Jonsson (2008) develop an exploratory conceptual model seeking to acknowledge the differences in the internationalization process, between the two types of fashion retailers: Incremental and Born-global. This study analyses the application of theories on fashion retail internationalization (in three perspectives: knowledge sharing, resource-based view, and psychic distance) for born-global retailers as 
they are to gradual-global retailers.

\subsubsection{Knowledge Sharing and Entry Mode}

Knowledge sharing is defined as "the way that a retailer gathers and diffuses proprietary market information" (Bhardwaj et al., 2011, p. 298), which is regarded as the key competitive advantage to enable sharing and exploiting worldwide, locally created knowledge (Kogut \& Zander, 1992). When a retailer becomes international, there are three types of knowledge sharing generating foreign market insight: forward, reverse, and lateral knowledge flow (Jonsson, 2008). Forward knowledge flow translates from headquarters to subsidiaries. Within a retailer's expansion, forward knowledge flow is useful that managerial expertise and the retail concept can be translated from headquarters to newer stores. Lateral flow occurs between subsidiaries, allowing stores that open in foreign markets to share experiences and customer interactions in the new location, with stores in other foreign markets. When a new store gathers unique information about a new market, reverse flow goes from subsidiaries to headquarters. The new stores need to successfully share information about the new market with headquarters in order for practices to be effectively adapted. The largest amount of learning about a new culture will occur within that culture (Jonsson, 2008). Thus when local employees utilize reverse knowledge flow, the global retailer gains greater insight into its new markets (Bhardwaj et al., 2011).

According to Kim and Hwang (1992), knowledge sharing is also considered as a transaction-specific variable that affects entry mode choice, including the value of retailer specific and tacit natural know-how. Retailer specific know-how is information that can be expressed in physical forms, such as manuals or directories. Tacit natural know-how is not embedded in physical knowledge but is instead knowledge gained through doing and communicating (Nonaka, 1994). This knowledge is transmitted within a retailer and is crucial to the company's decision of what kind of control they retain and the risk they will take, and will therefore help to form their ultimate entry mode choice. It is also suggested that a retailer with high levels of transaction-specific and tacit nature know-how would choose a high level of control when they internationalized, because they would not want to lose proprietary knowledge (Kim \& Hwang, 1992).

Therefore, Chetty and Campbell-Hunt (2004) and Bhardwaj et al. (2011) explain that Born-global retailers have three features: perceiving the world as one marketplace and may not have a strong domestic market as support to the internationalization process; risk-taking ability is higher among managers in such retailers, which results in adapting to and innovating in new environments more quickly; and asserting that prior experience and knowledge can be gained early on in life of the retailer. In contrast, traditional or gradual global retailers are described as a domestic orientation with a strong financial support for the internationalization process. For example, Wal-Mart took 30 years to establish its large domestic market before entering a neighbouring country, which enabled its "aggressive expansion" more recently (Arnold \& Fernie, 2000). Due to the aversion to take risks and a lack of knowledge, gradual retailers also internationalize through a slow learning process, where the actions and commitment of retailers are nurtured in their domestic market until they reach the expected performance levels (Anderson, 2000). This view of traditional global retailers emphasizes that commitment through incremental steps should be based on experience and gained knowledge about foreign markets (Bhardwaj et al., 2011).

\subsubsection{Resource-Based View}

Resource-based theory refers to a firm's ability to achieve and sustain competitive advantages (Wernerfelt, 1984) This theory is based on Dunning's $(1981 ; 1988 ; 2000)$ research on conceptualized resource advantages, which affected mostly the internationalization strategy as ownership-specific advantages and included two basic types of advantages: asset-based and transaction-based. Asset-based advantages refer to unique products or a company's reputation, such as private label clothing and uniquely recognizable products. Transaction-based advantages occur due to the way things are done within the retailer, including volume buying, economies of scale, and distribution advantages (Sternquist, 1997; Runyan, 2003).

In addition, these resources also have a significant effect on a firm's decision to, and method of internationalizing. According to the Strategic International Retail Expansion (SIRE) Model which is associated with stage theory, retailers tend to internationalize in two fundamental ways: Multinational or Global (Sternquist, 1997). A multinational retailer adapts its internationalization model to the culture to which it expands, and is willing to share and change its business format on the international stage, while global retailers use a standard retail format, and internationalize utilizing firm-specific resource advantages. In order to maintaining the ownership-specific advantages, retailers needs to keep a high level of control over how it internationalizes, preventing format duplication, and protecting secrets. Consequently, global retailers have decentralized management for better control over the expanding retailer (Sternquist, 1997). According to Burt (2002), he 
classifies global retailers as high fashion retailers and specialist chains, and multinational grocery retailers such as Ahold, which adapt their strategies to individual country markets.

According to the study developed by Bhardwaj et al. (2011), it concludes that Born-global retailers tend to be fully integrated, considering its marketplace as homogenous throughout the world and keeping the products standardized. Wal-Mart, for example, tended to copy the "Wal-Mart Way" in more distant markets during its aggressive expansion stage (1995-1999), such as Argentina, Brazil, China and Germany (Fernie et al., 2006). Not until the difficulties experienced in Germany and South Korea, did Wal-Mart enter into the third stage: a relatively prudent and slow development (Arnold \& Fernie, 2000). On the other hand, the traditional global retailers (e.g., Ahold) appear to be partially integrated, which suggests that its market may develop customized products based on target location (Chetty \& Campbell-Hunt, 2004). Furthermore, it also argues that Born-global retailers maintain long-term relationships and networks with intermediaries that have experiential knowledge instead of waiting to accumulate the knowledge themselves, while the traditional global retailers tend to build short-term relationships in early stages of internationalization and accumulate knowledge with time and experience (Bhardwaj et al., 2011).

\subsubsection{Psychic Distance}

As discussed above in psychic distance theories, the study developed by Bhardwajet al. (2011) compares Johanson and Wiedersheim-Paul's (1975) view with a psychic distance paradox (O'Grady \& Lane, 1996; Evans \& Mavondo, 2002). The psychic distance paradox argues a retailer may assume that the proximate market is similar enough as to not require market intelligence, while one who aims to enter a psychically distant market will work harder to gain knowledge of the market, and thus actually acquire a better understanding of this distant market (O’Grady \& Lane, 1996). Consequently, Bhardwajet al. (2011) explain that Born-global fashion retailers emphasize psychic distance is irrelevant for internationalization, while the traditional global fashion retailers assume that entering new markets as a function of the psychic distance to the prior experience (Chetty \& Campbell-Hunt, 2004).

In conclusion, the study developed by Bhardwaj et al. (2011) classifies retailers on the basis of the time taken and thus their strategy process as either incremental (traditional or gradual global) or dynamic (Born-global) (Figure 1). Furthermore, it also develops an exploratory conceptual model, which explains three strategy components for a born-global fashion retailer: greater knowledge sharing (all three types of knowledge sharing: forward, lateral and reverse); greater resource-based advantages (the high-risk, high-reward model); and least psychic distance (Bhardwaj et al., 2011).

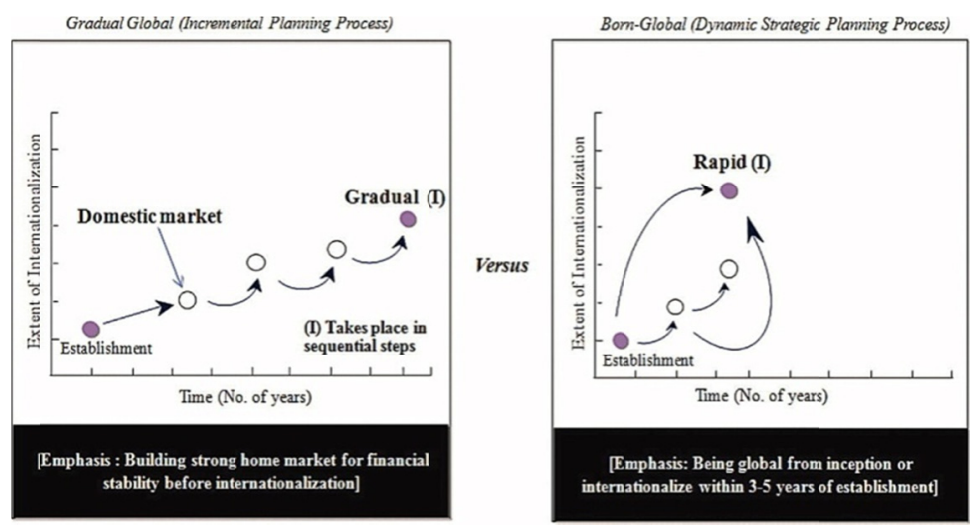

Figure 1. Gradual global versus born-global retail internationalization

Source: Bhardwaj et al., 2011, p. 297.

\section{Method}

\subsection{Research Strategy}

According to Ticehurst and Veal (2000), methodology refers to the way in which researchers approach problems and seek answers. The literature classifies research methodologies as quantitative or qualitative (Bryman \& Bell, 2011). Quantitative research is the systematic collection of numeric data that seeks to identify causal relationships and the results such as mathematical models, the academic theories and/or hypotheses (Taylor \& 
Bogdan, 1998). Common strategies can be experiments and surveys which are employed through self-completion questionnaires, structured interviews, and observations (Hair et al., 2003).

In contrast, qualitative research implies an emphasis on processes and meanings that are not measured in terms of quantity, amount, intensity or frequency, and provide a deeper understanding of the phenomenon within its context (Bryman \& Bell, 2011). It also creates a strong relationship between the researcher and the phenomenon under study (Hair et al., 2003). Possible strategies can be in the form of case studies, action research, participant observations, and personal documents such as diaries, letters, and journals (Saunders et al., 2007).

As mentioned above, the purpose of this research is to find to what extent the internationalization process of Zara and H\&M align with Incremental and Rapid Internationalization Models. With this objective, this research adopts a systemized structure capable of both explaining and predicting phenomena. This enables the researchers understand to how and why the fast fashion retailers internationalise from the social actors' own interpretation of their real life experiences, exploring their attitudes, values and beliefs about the research topic (Bryman \& Bell, 2011). Therefore, qualitative research based on an exploratory approachis recommended. The research significance indicates that not only it is descriptive, but also explanatory because an attempt has been made to explain the internationalization process of fast fashion retailers adopting internationalization models and theories that had been explored in studies in other contexts (Yin, 2009).

\subsection{Research Strategy}

There are two main reasons for choosing case studies as a research strategy in this study. Firstly, when considering research questions as the first condition for differentiating strategies, "how and why" questions lead to "case studies", "histories" and "experiments" as the preferred research strategies, while "what, who, where, how many and how much" questions refer to "survey" and "archival analysis" (Table 1). In this study, although the research questions are "how" questions types, a better understanding of the internationalization of fast fashion retailers is also pursued through answering "why" Zara and H\&M are able to gain competitive advantages through adopting international activities. Secondly, compared with "experiment" and "history" strategies, case studies are appropriate for examining contemporary events when the relevant behaviour cannot be manipulated (Table 1). Therefore, as the investigators have no control over the events and focus on both historical and contemporary events, the "case study" strategy is recommended in this research.

Table 1. Relevant situations for different research strategies

\begin{tabular}{llll}
\hline Strategy & Form of Research Questions & $\begin{array}{l}\text { Requires Control over Behavioral } \\
\text { Events }\end{array}$ & $\begin{array}{l}\text { Focus } \\
\text { Events }\end{array}$ \\
\hline $\begin{array}{l}\text { Experiments } \\
\text { Survey }\end{array}$ & How, Why & Yes & Yes \\
& Who, What, Where, & No & Yes \\
& How Many, & & \\
How Much & & Yes/No \\
Archival Analysis & Who, What, Where, How Many, & No & \\
History & How, Why & No & No \\
Case Study & How, Why & No & Yes \\
\hline
\end{tabular}

Source: Yin, 2009, p. 6.

\subsection{Selection of the Cases- $H \& M$ and Zara}

In this research, as "purposive and theoretical sampling" is adopted, three main criteria are defined for the selection of cases: convenience, access and geographic proximity (Bryman \& Bell, 2011; Yin, 2009).

There are two main reasons for selecting H\&M and Zara as the studying cases. Firstly, Zara, H\&M, and Gap are pioneers of "fashion retailer" principles operating with a chain of single-brand stores (Fernie \& Perry, 2011). Compared with only $38 \%$ ( $\$ 2,001 / 5,232$ millions) of net sales in Gap coming from its international activities, Zara and H\&M have a high degree of internationalization with $79 \%$ and $94 \%$ in 2011 , respectively (The Gap, 2011; Inditex, 2011a; H\&M, 2011a). Furthermore, regarding the definition of "fast fashion" in Chapter one, the lead time of three weeks enables Zara and H\&M to be considered as "fast fashion retailers", while Gap operates a one-year product life cycle (Ghemawat \& Nueno, 2006; Fernie \& Perry, 2011). Therefore, the two key words in the research questions are "fast fashion retail" and "internationalization" based on two criteria "accessibility" 
and "acceptance." H\&M and Zara are appropriate for this study, as they are "fast fashion retailers" with a high percentage of international sales. Additionally, since both H\&M and Zara are of European origin, it is also recommended to select them as samples on the basis of the criteria of geographic proximity.

Secondly, although both H\&M and Zara are considered as "fast fashion global retailers", there are a number of differences indicated by internationalization literatures including different types of fast fashion global retailers. $\mathrm{H} \& \mathrm{M}$ was described as a traditional/gradual internationalization retailer, which entered new markets with successively greater psychic distance and gained knowledge with time and experience (Johanson \& Wiedersheim-Paul, 1975; 1977). However, Zara was characterized as a born-global retailer, which emphasized psychic distance as irrelevant for internationalization and prior knowledge can be gained early on in life of the firm (Bell \& McNaughton, 2000; Bhardwajet al., 2011). The second difference relates to international production networks. H\&M outsourced a significant proportion of production to low costs countries such as China and Africa (Guercini \& Runfola, 2004), while Zara owned 17 worldwide manufacturing subsidiaries, enabling an agile supply chain with a high level of responsiveness to emerging fashion trends (Tokatli, 2008).

Therefore, since both similarities and differences can be exploited for examining applications of two models, $\mathrm{H} \& \mathrm{M}$ and Zara are appropriate for this multiple-case study research.

\subsection{Data Collection}

According to Saunders et al. (2007), there are two categories of data: primary andsecondary data.Primary data is collected specifically for a particular research project and traditionally through direct observations, surveys, interviews and company documents. On the other hand, secondary data refers to the data that is analysed from earlier studies where the combination of raw data and summaries can form new data and new relationships (Saunders et al., 2007).

Since this research is based on an exploratory approach employing deductive reasoning, both primary (company documents and press releases) and secondary data (published reports) are chosen as the data collection method. Firstly, the majority of data collection of this research is based on the primary data in organizational documents from the public domain, including company annual reports, press releases, transcripts of chief executives' speeches and public-relations material on the official websites. Secondly, as secondary data could utilize high-quality data for a short-term research project (Bryman \& Bell, 2011), secondary data is also collected in this research from organisational reports such as Harvard Business School reports. Therefore, as these documents can offer insights into managerial decisions and actions, the international decisions and activities of both H\&M and Zara can be analysed in depth to present a clear picture examining the applications of two models in reality.

\section{Data Description}

\subsection{Case I: Zara}

\subsubsection{Background of Zara}

Zara is one of the hottest fast fashion retailers of the $21^{\text {st }}$ century (Ghemawat \& Nueno, 2006). Founded in 1975, Zara's parent, Inditex, has become one of the leading global apparel retailers (Inditex, 2011a; Ghemawat \& Nueno, 2006). With its initial public offering (IPO) in 2001, Inditex's sales and profits have experienced significant growth for its eight brands (Figure 2), of which Zara contributes 64.8\% of the total sales in 2011 (Inditex, 2011a). As shown in Figure 4.1, the net sales revenue of Inditex Group has dramatically grown from $€ 3,250$ million in 2001 to $€ 13,793$ million in 2011 , with Zara's growth from $€ 2,477$ to 8,928 million. This rise around the world has in turn generated significant profits. Regarding sales among the pioneers of global fashion retailers, both Gap (\$14,549 million) and H\&M (\$15,789 million) are still bigger than Zara $(\$ 10,894$ million) in 2011, but Zara's 19.2\% margins beat Gap's 9.9\% and H\&M's 18.5\% (The Gap, 2011; Inditex, 2011a; H\&M, 2011a). Overall, Zara's growth, to a large extent, benefits from its specific retail concept and strategies of internationalization. 


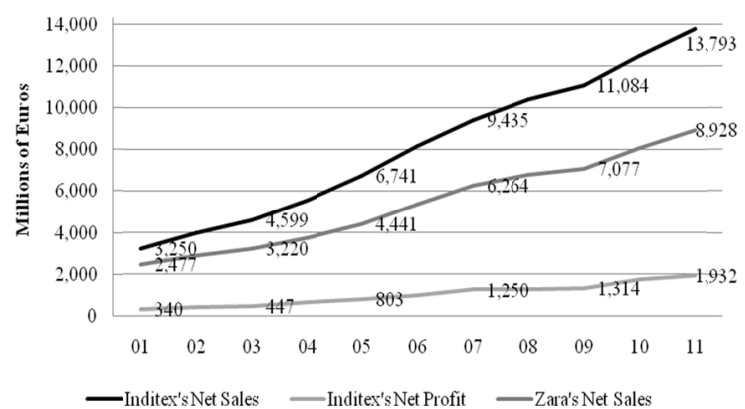

Figure 2. Evolution of the results in inditex group and zara (2001-2011)

Source: Data are collected from the annual reports of Inditex, 2001a-2011a.

\subsubsection{Internationalization of Zara}

With the opening of a store in Oporto (Portugal) in 1988, Zara started its international expansion. By the end of 2011 fiscal year, the total number of stores owned by Zara around the world is 1,830 in 82 countries: 1,279 stores were located in Europe (493 in Spain), 207 in America, and 344 in Asia and the rest of the world (Inditex, 2007a;2008a; 2011a). Overall, international operations accounted for $73 \%$ of Zara's stores and $79 \%$ of its sales in 2011, and had been steadily increasing its shares of those totals (Inditex, 2011a). In this case study, four based perspectives will be discussed in terms of the internationalization process of Zara: International Presence, Entry Modes, International Marketing, and International Management.

\subsubsection{International Presence and Market Selection}

As shown in Figure 2, the expansion process of Zara can be divided into three stages: Domestic Market (1975-1987), Slow Expansion (1988-1997), and Aggressive Expansion (1998-present).

\section{Domestic Market (1975-1987)}

In this period, Zara extended its network of retail stores to major Spanish cities, focusing the expansion on the domestic market (Inditex, 2012a).

\section{Slow Expansion (1988-1997)}

Zara's international expansion began in 1988 with the opening of a store in Oporto in northern Portugal. Between 1989 and 1997, it added one or two countries per year to its market portfolio. By the end of this stage, there were Zara stores in nine European countries, the United States, and Israel.

\section{Aggressive Expansion (1998-present)}

Since 1997, Zara became more determined and entered the third stage which can be called "aggressive expansion". Between 1998 and 2003, Zara consolidated its position in the Europe with 36 new-added countries, instead of gaining a foothold in other more distant countries (Figure 3). However, since 2004, Zara began to focus on Asia as the company's priority for expansion (Inditex, 2011a). In 2011, 59 stores were opened in this region, comprising $55 \%$ of total openings. China deserves a special mention as it saw 30 new stores, where the chain already has over 100 stores. In Asia, the number of new stores in Japan and South Korea, with 11 and 7 openings respectively is also important (Inditex, 2010a; 2011a). 


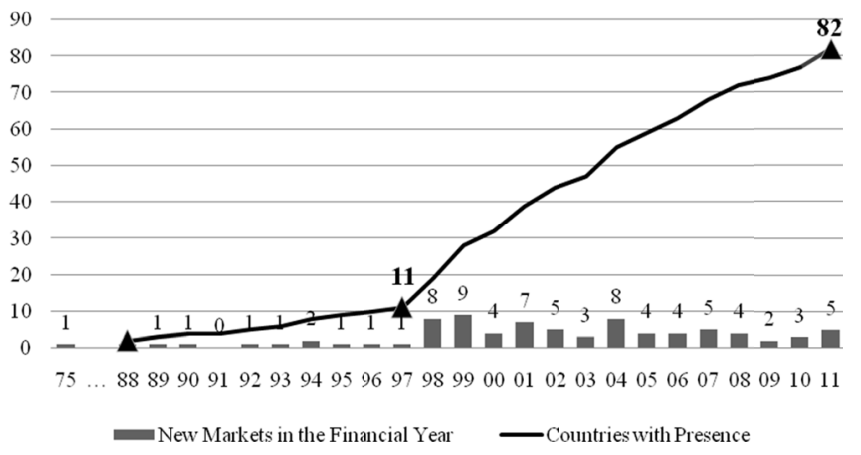

Figure 3. The expansion process of zara (1975-2011)

Source: Data are collected from the annual reports ofInditex, 1998a-2011a; and, the press release document Inditex, 2012a.

\subsubsection{Market Entry}

While all of Zara's stores in Spain were company-owned, three modes of market entry were adopted for its international expansion: own subsidiaries, franchising and joint ventures.

\section{Own subsidiaries}

Zara had originally internationalized through company-owned stores and, at the end of 2011, operated 1,648 such stores presenting $87 \%$ of the total number of stores (Inditex, 2011a). Zara typically adopted this direct market entry strategy into the Western countries with similar society environment and aesthetic standard, such as the majority of European and South American countries (Inditex, 2012a).

\section{Franchising}

Zara implemented franchises in "countries that were small, risky, or subject to significant cultural differences or administrative barriers", such as Andorra, Iceland, and Poland in Europe, and especially the Middle Eastern countries (where restrictions on foreign ownership ruled out direct entry) (Ghemawat \& Nueno, 2006, p. 17). By the end of 2011, 182 franchised stores were operated by Zara around the world, presenting $7.9 \%$ of the total net sales (Inditex, 2011a).

\section{Joint ventures}

Zara used joint ventures in five larger, more important markets-Japan, Germany, Italia, South Korea, and India, where there were barriers to direct entry, especially the difficulty of obtaining prime retail space in city centers (Inditex, 2012a). In 2008, the decision to link with the Lotte Group, holding $80 \%$ of the joint venture enabled Zara to open its first store in Young Plaza, one of the highest-traffic department stores in Korea owned by this partner (Inditex, 2008a; Inditex, 2008b). More recently, in 2010, Inditex and the Tata Group signed an agreement to form a 51-49 joint venture to develop Zara's first store in the Indian capital, Delhi, in the Select CityWalk shopping Centre (Inditex, 2010b).

According to the press release document published by Inditex in 2012a, Zara was described as following a specific pattern of expansion. Once the entry decision is made for a particular country a flagship store in a strategic area is opened, examples include the emblematic stores in Sydney's Pitt Street, Melbourne's Burke Street, and Taiwan's Taipei 101 building (Inditex, 2011a). After developing some operating experience locally, it would add stores in adjoining areas in that country. Furthermore, this accumulated experience and knowledge also enables Zara to increase the ownership in its franchising (i.e., Turkey, Russia, Kazakhstan) and joint venture (i.e., Germany, Italy) agreements for a higher level of control (Inditex, 1999a; 2005b; 2006b; 2006c; 2006d; 2012a).

\subsection{Case II: $H \& M$}

\subsubsection{Background of H\&M}

Founded from a single womenswear store in 1947 in Viisteras, a small Swedish town, Henners \& Mauritz (H\&M) has developed to be a global leading retailer offering fashion for the whole family, and their home, consisting mainly of sales of clothing, accessories, footwear, cosmetics and home textiles to consumers (H\&M, 2011a; 2012a). Although facing strong competition from Zara who has become the largest global fashion retailers since 2006, H\&M's sales and profit have increased significantly in the recent years due to the growth of the whole 
marketplace. As shown in Figure 4, by the end of the 2011 fiscal year, it experienced an increase sales from SEK 59,699 million in 2001 to 109,999 million in 2011, with net profit rising from SEK 5,478 to 20,379 million. Similarly, H\&M's growth also benefits from its retail concept and international markets.

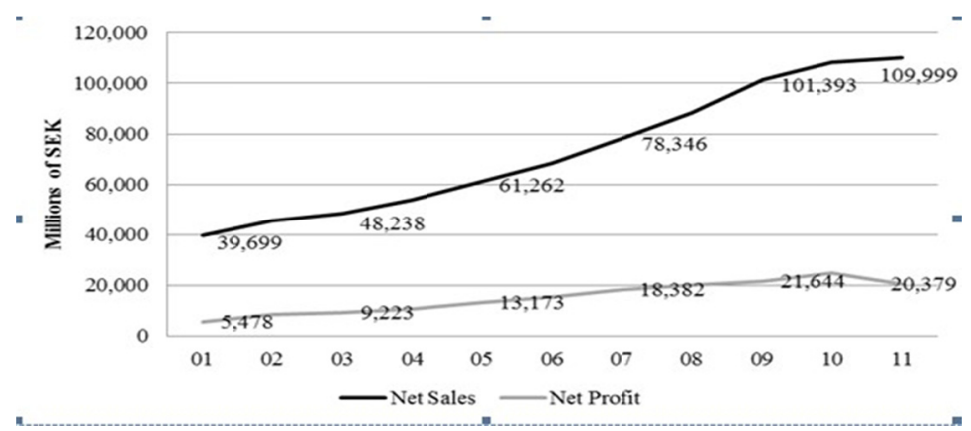

Figure 4. Evolution of the results in H\&M (2001-2011)

Source: Data are collected from the annual reports of H\&M, 2001a-2011a.

\subsubsection{Internationalization of $\mathrm{H} \& \mathrm{M}$}

Since H\&M started its global expansion in 1964 by entering into Norway, it has experienced substantial growth in international marketplace. By the end of 2011 fiscal year, H\&M owned 2,472 stores around the world in 43 countries. 2,007 stores were located in Europe (173 in Sweden), 291 in North America, 104 in Asia, and 70 in Middle East and Northern Africa (H\&M, 2011a). Overall, international operations accounted for 93\% of H\&M's stores and 94\% of its sales in 2011 (H\&M, 2011a). In this case study, four based perspectives will be discussed in terms of the internationalization process of H\&M, International Presence, Entry Modes, International Marketing, and International Management.

\subsubsection{International Presence and Market Selection}

As shown in Figure 4.4, compared with Zara, the expansion process of H\&M was relatively longer and slower, which also can be divided into three stages: Domestic Market (1947-1964), Slow Expansion (1965-1998), and Fast Expansion (2000-present).

\section{Domestic Market (1947-1964)}

As with Zara, H\&M focused on its domestic markets during this period.

\section{Slow Expansion (1965-1998)}

H\&M's international expansion began with the opening of a store in Norway in 1964 and Denmark in 1967. However, it experienced a much longer and slower period in this stage with 33 years compared with Zara's 9 years. Between 1965 and 1998, it added one country every two or three years to its market portfolio (Figure 5). By the end of this stage, there were H\&M stores in 12 European countries.

\section{Fast Expansion (2000-present)}

Since 2000 H\&M entered Spain and the first market outside Europe - The US, it became faster in the internationalization process. Especially in 2007, two full-concept H\&M stores opened in the dynamic metropolis of Shanghai, China; and in 2008, it entered Japan and 11 countries in Middle East and Northern Africa (H\&M, 2012b). In this period, H\&M's international growth target remained to increase the number of stores by 10-15 percent per year, while 275 new stores are planned for 2012 with China, the US and the UK as its largest expanding markets (H\&M, 2011a). 


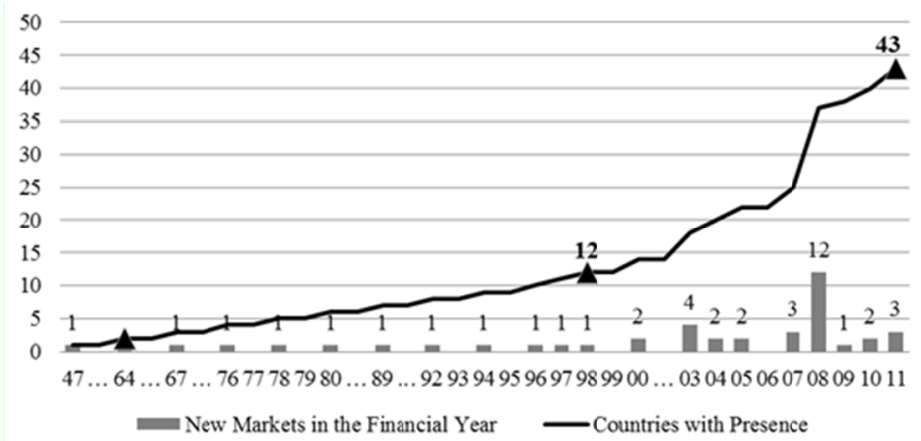

Figure 5. The Expansion Process of H\&M (1947-2011)

Source: Data are collected from the annual reports of H\&M, 1996a-2011a; and, the official website of H\&M, 2012a; 2012b.

\subsubsection{Market Entry}

Two modes of market entry were utilized for H\&M's international expansion: franchising and own subsidiaries.

\section{Franchising}

Similarly to Zara, H\&M entered 11 countries in Middle East and Northern Africa through franchising agreements with one of the Middle East's leading retailers, M.H. Alshaya (H\&M, 2006b). By doing this, H\&M is able to bring its fashion to a part of the world where it would not otherwise be possible to establish a presence, using the current H\&M wholly-owned subsidiary model (H\&M, 2006b). By the end of 2011, 70 franchised stores were operated by H\&M, presenting only $1.1 \%$ of the total net sales (compared with Zara's $7.9 \%$ ) (H\&M, 2011a).

\section{Own subsidiaries}

The current H\&M wholly-owned subsidiary model is adopted in the majority of its international markets- 26 in Europe, 2 in North America (The US and Canada), and 4 in Asia (Japan, China, South Korea, and Singapore). At the end of 2011, its 2,402 company-owned stores contributed $98.9 \%$ of the total net sales, showing a larger percentage than Zara's 87\% (H\&M, 2011a).

\section{Discussion}

\subsection{Incremental Internationalization Models- $H \& M$}

According to Bhardwajet al. (2011) and Chetty \& Campbell-Hunt (2004), H\&M was characterized as a typical traditional/gradual fast fashion retailer. Based on this traditional model, retailers learn and acquire knowledge on a specific market with time and experience during different stages of the process. As the retailers gain knowledge, their level of commitment to invest in more resources increases, though it is a gradual and incremental process (Jonsson, 2008). More specifically, three perspectives: Knowledge Sharing, Resource-based View, and Psychic Distance, will be discussed within the reality of H\&M's internationalization process.

\subsubsection{Knowledge Sharing and Entry Mode}

Three basic characteristics were described in terms of fast fashion retailers' knowledge sharing and entry mode which applied Incremental Internationalization Models: strong domestic market, Gradual knowledge acquisition, and low risk-taking ability, while H\&M only matched part of what the model suggested in this case.

In this case, before resorting to internationalization, $H \& M$ built a successful domestic market for supporting its later international decisions, which followed this model. According to the Establishment Chain of U-Model (Johanson \& Wiedersheim-Paul, 1975), firms that internationalize utilizing this strategy, emphasize having a strong base in the home market before trading internationally as it helps to maintain financial stability (Chetty \& Campbell-Hunt, 2004). In 1947, H\&M was founded from a single womenswear store in Viisteras, a small Swedish town, followed by the next store just two years later (H\&M, 2012a). As H\&M's approach to fashion is well received by the public, the retailer enabled to extend its network of stores to major Swedish cities, such as in Stockholm in 1952 (H\&M, 2012a). Therefore, these domestic developments in 17 years (1947-1964) enabled $\mathrm{H} \& \mathrm{M}$ to secure its position in the home market before internationalization. However, over the past 45 years of internationalization, only $6 \%$ of the total sales were sourced from its domestic market, accounting for $7 \%$ of the total number of stores, while the largest markets in Germany, USA and UK, contributed over $38 \%$ of the total 
sales (H\&M, 2011a). This later much smaller home market cannot be considered as a strong support for H\&M's recent rapid internationalization process (at least in the last ten years.

Another significant characteristic of the Incremental Internationalization Models assumes a commitment through incremental steps to gradually build on experience and gain knowledge about foreign markets (Johanson \& Vahlne, 1977; Chetty \& Campbell-Hunt, 2004). In this case, H\&M followed this pattern in its slow expansion stage (entering 12 European countries in 33 years), providing the retailer enough time to accumulate overseas experience and identify strategies that can be successful enough to apply to their international operations. Nevertheless, in its later stage - Rapid Expansion (2000-present), H\&M broke down this traditional model in its Middle East countries, where it acquired market knowledge from its local partner through franchising agreements. With this previous knowledge gained early, H\&M entered 11 Middle East countries in the same year -2008 (H\&M, 2012b).

On the other hand, as opposed to what Incremental Internationalization Models suggested, H\&M maintained both three types of knowledge sharing (forward, lateral, and reverse) flexibly. For example, regarding the forward knowledge flow, H\&M emphasised maintaining a corporate spirit, and therefore all new store employees received a three-week introduction course internally and got assigned a mentor (EMCC Case Studies, 2004). While H\&M's lateral knowledge flow allowed stores that opened in a foreign market to share daily information and was responsible for the sales and stock management such as the need for restocking and procurement between stores (H\&M, 2011a). However, as store managers were responsible for following new market trends and competitors at a local level, and then reporting these to its central office, to a large extent, $\mathrm{H} \& \mathrm{M}$ benefited from this reverse knowledge flow for acquiring local knowledge and information rapidly in its later expansion stage. Overall, all these three types of knowledge sharing were facilitated by its ICT system from the head office in Stockholm to the individual stores, the central warehouse, and the procurement department/production offices, enabling both front-end and back-end data sharing and integration (H\&M, 2011a) This fitted the knowledge flow model, which was characterized by Rapid Internationalization Models (Kim \& Hwang, 1992).

Furthermore, H\&M was not matching the characteristic of Incremental Internationalization Models in terms of the low risk-taking ability in its internationalization process. In the recent literature, H\&M was described as a traditional/gradual fast fashion retailer who avoided risk taking and lacked of knowledge, which resulted in lower-risk entry mode decisions and slow nature of learning process (Bhardwaj et al., 2011; Chetty \& Campbell-Hunt, 2004). However, H\&M's knowledge sharing established the presence of exchange of firm-specific and local-level knowledge in its international operations, which supported the high-control entry mode internationalization model used by H\&M with over $98.9 \%$ wholly-owned subsidiaries in foreign markets in 2011 (compared with Zara's 87\%) (Meyer et al., 2009; H\&M, 2011a; Inditex, 2011a).

\subsubsection{Resource-Based View}

Regarding the resource-based view of internationalization process, traditional/gradual fast fashion retailers were specified as being partially integrated, developing customized products based on target location, maintaining short-term relationship and accumulating knowledge with time and experience (Chetty \& Campbell-Hunt, 2004). In other words, the international objectives of traditional/gradual retailers were considered as firm survival and gaining market share, compared with born-global retailers' competitive advantages, "looking-in" customers, and protecting and exploiting proprietary knowledge (Bell \& McNaughton, 2000). In this case, H\&M did not fit the Incremental Internationalization Models in terms of its resource-based view.

While H\&M was regarded as a traditional/gradual fast fashion retailers that was partially integrated, this case reveals H\&M was suggested as fully integrated in the retail concept controlling each level of its supply chain-design, manufacturing, logistics and store management. Focusing on the customer, H\&M's design and buying department created the collections centrally, which was fully controlled by the head office in Stockholm (H\&M, 2011a). Although over 700 independent suppliers for its manufacturing were located around the world, H\&M maintained local production offices in Asia and Europe, aiming to guaranteeing the quality of the products and that manufacturing takes place under good working conditions (H\&M, 2011a). This close cooperation with the suppliers benefited H\&M's vertical integrated retail concept with high levels of control from the production offices. Furthermore, its back-end integration was created by the central distribution centre located in Germany that served as the transit terminal and where the store managers reports to the head office in Stockholm following new market trends and competitors at a local level (H\&M, 2011a; EMCC Case Studies, 2004). Therefore, with this vertical integrated company, H\&M controlled each level of its design, production, distribution and sales leading to global competitive advantages: customer orientation, short lead times and 
cost-efficient production, which did not follow what Incremental Internationalization Models suggested as partially integrated.

Additionally, as opposed to the short-term relationships of traditional/gradual fast fashion retailers, H\&M's strong O-specific advantages also resulted from its long-term relationships and networks with the suppliers (Chetty \& Campbell-Hunt, 2004). For instance, H\&M's code of conduct was maintained as an ethical document to build long-term labour relations with its global suppliers, thereby it was able to exploit economies of scale for lower product costs, and the suppliers had a loyal customer (EMCC Case Studies, 2004).

On the other hand, being different from what has been suggested as a traditional/gradual fast fashion retailers that it would develop customized products based on local level, the O-specific advantages led to H\&M's worldwide standardized strategy and limited activities were adapted to the target markets in its internationalization process for protecting and exploiting these proprietary knowledge (Bell \& McNaughton, 2000). In this case, it maintained the same basic international marketing format around the world, for example, over $80 \%$ of its product range was the same in all markets, and standardized promotion guidelines were transmitted to the individual stores (EMCC Case Studies, 2004; H\&M, 2011a).

\subsubsection{Psychic Distance}

In this case, H\&M matched the traditional psychic distance model of U-Model in its expansion process (Johanson \& Wiedersheim-Paul, 1975). The traditional Incremental Internationalization Models implied that firms enter new markets with successively greater psychic distance (Andersen, 1993; Johanson \& Vahlne, 1990). This suggests firms enter a particular market close to and similar to the home country before expanding into more distant and dissimilar markets. In 1964, H\&M opened the first store outside Sweden in Norway, which is next to its domestic market with a similar culture with the smallest psychic distance (the greatest sources of influence on Swedish culture came from Denmark, Norway and England in the early Middle Ages) (Hofstede, 1991; H\&M, 2012b). Since then, during the early slow expansion stage (1965-1998), all of its 12 new foreign countries (i.e., United Kingdom, Switzerland, Germany, and Netherlands) were within limited psychic distance, similar European culture, and a common language and religion (Hofstede, 1991).

Furthermore, after experiencing 33 years in 12 markets with less psychic distance, H\&M began to open stores in two more psychically distant markets in 2000: Spain and the US (H\&M, 2012b). As H\&M gained knowledge through its vertical integration, it expanded quickly to other more distant and dissimilar markets. In 2007, H\&M extended its expansion network into China and Japan. It also entered 11 Middle East countries with a greater psychic distance in 2008 (Hofstede, 1991). It seems that the company lay in the paradox framework of Evans and Mavondo (2002) in this stage, emphasizing that psychic distance is irrelevant for internationalization. However, before entering these greater psychic distance markets (Japan and Middle East countries), H\&M gained knowledge from its less psychic distance markets firstly in 33 years (i.e., Norway, Denmark, and Switzerland), and then more distant ones in 7 years (i.e., Spain and the US). Therefore, although it was able to accelerate the internationalization process and move more quickly to psychically distant markets in the later stage, H\&M still followed the traditional psychic distance model of U-Model: entering new markets with successively greater psychic distance (Johanson \& Wiedersheim-Paul, 1975).

\subsection{Rapid Internationalization Models-Zara}

Significantly being different from H\&M, Zara was considered as a born-global fast fashion retailer by recent literature (Bhardwaj et al., 2011; Caro et al., 2010; Lopez \& Fan, 2009). On the basis of Rapid Internationalization Models, Zara was described as maintaining three basic characteristics in terms of its internationalization process: Great knowledge sharing (non-strong domestic market before internationalization; all three types of knowledge sharing; higher risk-taking ability; early experience and knowledge gaining on in life of the firm); competitive resource-based advantages (fully integration; standardisation; long-term relationship and networks with intermediaries); and irrelevant psychic distance (Chetty \& Campbell-Hunt, 2004; Bell \& McNaughton, 2000). However, in this case, Zara appears not to totally follow the Rapid Internationalization Process.

\subsubsection{Knowledge Sharing and Entry Mode}

In this case, Zara did not follow the born-global model in its early internationalization process (1988-1997) with previous successful domestic market's support and incremental/gradual steps on experience and knowledge acquisition, while the company matched the model in the later aggressive expansion stage since 1998.

Before trading internationally (1988), Zara had a strong base in the home market for maintaining a financial stability, following the Establishment Chain of U-Model instead born-global model (Johanson \& 
Wiedersheim-Paul, 1975). On the one hand, since its foundation in 1975, Zara's approach to fashion was well received by the domestic market, enabling the retailer to extend its network of stores to major Spanish cities (Inditex, 2012a). These developments in domestic markets (13 years) before going international, to a large extent, benefited its early slow internationalization stage (1988-1997). On the other hand, between 1985 and 1987 , Inditex's manufacturers devoted their entire output to Zara, which laid the foundations for a distribution system that can meet the needs of its expected rapid pace of global growth (Inditex, 2012a).

Additionally, during its early slow internationalization stage, instead of utilizing born-global model, Zara also adopted the stage model for gaining experience and knowledge: acquiring experience and knowledge about foreign markets through incremental steps (Bell \& McNaughton, 2000). Between 1988 and 1997, it only added one or two countries per year to its market portfolio (at a median distance of about 3,000 kilometres from Spain), which guaranteed the company enough time to accumulate local experience and knowledge.

Nevertheless, after nine years initial movement, Zara entered into an aggressive internationalization stage (1998-present), which applied to the born-global model with greater knowledge sharing, high risk-taking ability and early experience and knowledge gaining on in life of the firm (Bhardwaj et al., 2011).

Firstly, as born-global model suggested, Zara maintained both three types of knowledge sharing (forward, lateral, and reverse) in international activities. Forward knowledge flows, for example, could be created through the IT system for transmitting information of product design collections or corporate decisions to its individual stores around the world (Inditex, 2012a). While Zara's later rapid internationalization process may, to a large extent, benefit from the reverse knowledge sharing, which fitted what the knowledge flow model suggested that reverse knowledge flow is more important for successful globalization (Kogut \& Zander, 1992; Jonsson, 2008). Zara's reverse-flow was created via its worldwide IT system for exchange information from individual stores to headquarters, especially retailing store manager's and trend spotter's daily reports, representing as "a vehicle for gathering market information, sending feedback to design teams and reporting on trends requested by customers" (Inditex, 2012a, p. 8). These three knowledge flows allowed both explicit and tacit knowledge (i.e., specific knowledge of product sales, customer reaction to new products and local trends) to be exchanged from the foreign units, back through the home office and then back out to the foreign units, and thus generated a combination of benefits for Zara including its transaction-specific types of overseas knowledge (Kim \& Hwang, 1992).

Secondly, with these unique knowledge sharing capabilities, Zara was able to adopt high-control and high-risk internationalization entry strategy with $87 \%$ of the total number of stores in foreign markets through wholly-owned subsidiaries in 2011 (Inditex, 2011a). Furthermore, after developing experience operating locally, Zara increased the ownership in its franchising (i.e., Turkey, Russia, and Kazakhstan) and joint venture (i.e., Germany, Italy) agreements for a higher level of control, which fitted what born-global model suggested that higher risk-taking would result in adapting and innovating in new environments more quickly (Chetty \& Campbell-Hunt, 2004).

Finally, as opposed to gaining experience and knowledge about foreign markets incrementally in traditional/gradual fast fashion retailers, Zara added 6 countries on average per year to its market portfolio (71 new markets in 12 years) during its aggressive internationalization stage (1998-present), which resulted in acquiring knowledge at a local level for the next new market. Furthermore, it was able to acquire the prior experience and knowledge early on in life of the firm through its partnerships with franchising and joint ventures agreements in foreign countries with more cultural differences or administrative barriers. Therefore, in terms of acquiring specific knowledge and experience, Zara fitted the born-global model in its aggressive internationalization stage (1998-present).

\subsubsection{Resource-Based View}

In this case, Zara partly followed the resource-based view of born-global fast fashion retail internationalization model with a fully integrated and long-term relationship with some particular intermediaries for experiential knowledge acquisition, while the company kept parts of its adaptations to international activities, which was different from the born-global model's view (Bell \& McNaughton, 2000; Chetty \& Campbell-Hunt, 2004).

Following the born-global model, although both Zara and H\&M were characterized as vertically integrated, fitting the born-global internationalization model, they achieved this fully integration through different types of supply chain models (Fernie \& Perry, 2011). H\&M fully outsourced production but maintained a fully integrated design, logistics system and retailing stores through utilizing ICT-system linking with its central office in Stockholm. Zara kept control of a large proportion of its fashion products through company-owned factories to achieve vertical integration. Therefore, as the born-global model suggested, Zara's vertical integrated retail 
concept resulted in unique competitive advantages: updating merchandise to customer tastes in the shortest time - "new garments land in stores twice weekly" (Inditex, 2012a, p. 6).

On the other hand, rather than entirely correlating with the born-global model, Zara combined different parts of the standardization and adaptation concepts in its international retailing operations, although its parent company - Inditex used the same basic format in all fashion concepts for protecting its strong O-specific resources. For instance, it selected market entry through following the standard procedures in a commercial team from headquarters to study a specific entry opportunity, while the actual application of this template for market analysis varied somewhat from country to country (i.e., the opening of the first store in New York for informational purposes) (Ghemawat \& Nueno, 2006). Furthermore, compared with H\&M's high-level standardization, Zara adapted its prices and positions globally on the basis of different market characteristics, but standardized its product designs and promotion (Inditex, 2012a).

Additionally, being partly associated with the born-global model, Zara just maintained long-term relationships with intermediaries (i.e., franchising and joint venture partners) in some particular countries to acquire experiential knowledge during its aggressive internationalization stage (1998-present), instead of waiting to accumulate the knowledge itself, while it took incremental steps to gain knowledge from foreign markets with time and experience in the early slow internationalization stage (1988-1997).

\subsubsection{Psychic Distance}

In this case, instead of entirely correlating with the born-global model, Zara followed the traditional psychic distance model of U-Model in its slow internationalization stage (1988-1997), while it maintained relatively weakened correlation between the entered foreign markets and psychic distance in the later aggressive expansion process (1998-present) (Johanson \& Wiedersheim-Paul, 1975).

During the slow internationalization stage (1988-1997), with the classic psychic distance model of Johanson and Vahlne $(1975 ; 1977 ; 1990 ; 2009)$, Zara first expanded into geographically and/or psychologically proximate markets with a minimum level of socio-economic development, before expanding into more distant and dissimilar markets. In 1988, Zara began international expansion with the opening of a store in Portugal, which was a familiar market due to its geographical and cultural proximity to Spain (Hofstede, 1991). Between 1988 and 1997, it entered one or two countries per year (at a median distance of about 3,000 kilometres from Spain), such as in 1990 France -"a geographically contiguous country and a starting point for the later expansion in Northern Europe-Belgium and Sweden in 1994". In 1992 it entered Mexico - "though geographically distant, was culturally close to the home country, and provided with a reference of the South American market" (Lopez \& Fan, 2009, p. 10).

As Zara gained knowledge through its backwards integration and early internationalization, it expanded rapidly (since 1998) to other foreign markets with less cultural or geographical proximity. As the traditional model suggested that after entering geographically and/or psychologically proximate markets, expansion would move to more distant markets (Johanson \& Vahlne, 1975; 1977; Andersen, 1993), Zara seemed to follow this model. However, another crucial characteristic of the traditional model was described that this process should be operated in a gradual manner (O'Grady \& Lane, 1996). In this case, during the later aggressive expansion process, Zara was able to significantly accelerate the process for entering greater psychically distant markets, and then extended its stores networks rapidly in those countries, such as China (101 stores in 5 years) and South Korea (34 stores in 3 years). Therefore, instead of entirely correlating with the traditional or born-global model, Zara's international strategy combined the divide between the classic psychic distance model of Johanson \& Vahlne $(1975 ; 1977)$ and the paradox framework of O'Grady \& Lane (1996) and Evans \& Mavondo (2002).

\subsection{Summary of H\&M and Zara in Two Models}

In conclusion, two conclusions can be drawn in this discussion. Firstly, both H\&M and Zara did not entirely correlate with the expectations of Incremental and Rapid Internationalization Models, which appears to be significantly different from what have mentioned in the Literature Review that concluded that Zara was a born-global fast fashion retailer and H\&M was a traditional/gradual global one. Secondly, another conclusion is that in these two representative fast fashion retailers, Rapid Internationalization Models were not adopted completely independently, while to a large extent, Incremental Models were still relevant, especially in their early expansion stages.

\section{Conclusion}

This research has looked into two internationalization process models - Incremental and Rapid Internationalization - in terms of fast fashion retailing. It aimed to critically introduce and discuss how two 
representative global fast fashion retailers - H\&M and Zara - align with these two models through a multiple-case study. Based on this, two conclusions can be drawn in this research. Firstly, both H\&M and Zara did not entirely correlate with the expectations of Incremental and Rapid Internationalization Models. This appears to be significantly different from what has been mentioned in the literature review, which concluded that Zara was a born-global fast fashion retailer and H\&M was a traditional/gradual global one. Secondly the two fast fashion retailers adoption of the Rapid Internationalization Models were not adopted completely independently; while to a large extent, the Incremental Models were still relevant, especially in their early expansion stages. These findings remain speculative and provocative and would therefore contribute to the existing literatures in fast fashion retailing.

In this case, H\&M did not entirely align with Incremental Internationalization Models as a traditional/gradual fast fashion retailer in the recent research (Bhardwajet al., 2011; Chetty \& Campbell-Hunt, 2004), but involved part of Rapid Models. H\&M's successful domestic market strategy before going international, the gradual experience and knowledge acquisition during early slow expansion stage (1965-1998), and utilizing the traditional psychic distance model (Johanson \& Vahlne, 1975; 1977) in its expansion process are characterized in the gradual model. On the other hand, H\&M also maintained several differences from this traditional model, such as a vertical integrated retail concept, strong O-specific competitive advantages, high risk-taking ability of entry mode, and short-term relationships and networks with its suppliers, which enabled the company's later fast internationalization process.

Compared with H\&M, a relatively larger proportion of Zara's international activities and strategies aligned with the expectations of Rapid Internationalization Models as a born-global fast fashion retailer, while part of it remained relevant with the Incremental Models. Zara achieved all three types of knowledge sharing (forward, lateral, and reverse) with O-specific competitive advantages, which enabled its high risk-taking ability of entry mode and later aggressive internationalization. However, in the beginning of its internationalization, Zara still followed the traditional stage model for gaining knowledge about foreign markets through incremental steps to gradually build on experience and entering new markets with successively greater psychic distance.

Therefore, instead of entirely correlating with the traditional or born-global model in recent literature, both H\&M and Zara combined the divide between two models, and appeared to adopt the traditional stage model in their early process, which suggested that stage model was still relevant.

\section{References}

Alexander, N. (1997). International Retailing. Oxford: Blackwell.

Andersen, O. (1993). On the internationalization process of firms: A critical analysis. Journal of International Business Study, 24(2), 209-231. http://dx.doi.org/10.1057/palgrave.jibs.8490230

Anderson, T. J. (2000). Strategic planning, autonomous actions and corporate performance. Long Range Planning, 33, 184-200. http://dx.doi.org/10.1016/s0024-6301(00)00028-5

Arnold, S. J., \& Fernie, J. (2000). Wal-Mart in Europe: prospects for the UK. International Marketing Review, 17(4/5), 416-432. http://dx.doi.org/10.1108/02651330010339932

Autio, E., Sapienza, H., \& Almeida, J. (2000). Effects of age at entry, knowledge intensity, and imitability in international growth. Academy of Management Journal, 43(5), 909-924. http://dx.doi.org/10.2307/1556419

Barnes, L., \& Lea-Greenwood, G. (2006). Fast fashioning the supply chain: Shaping the research agenda. Journal of Fashion Marketing and Management, 10(1), 259-271. http://dx.doi.org/10.1108/13612020610679259

Bell, J. (1995). The internationalization of small computer software firms-A further challenge to "stage" theories. European Journal of Marketing, 29(8), 60-75. http://dx.doi.org/10.1108/03090569510097556

Bell, J., \& McNaughton, R. (2000). "Born Global" firms: A challenge to public policy in support of internationalization. In J., Pels \& D. W., Stewart (Eds.), Marketing in Global Economy, Proceedings (pp. 175-185). Buenos Aires: American Marketing Association (AMA). http://dx.doi.org/10.4337/9780857938046.00020

Bhardwaj, V., \& Fairhurst, A. (2010). Fast fashion: response to changes in the fashion industry. International Review of Retail, Distribution \& Consumer Research, 20(1), 165-173. http://dx.doi.org/10.1080/09593960903498300

Bhardwaj, V., Eickman, M., \& Runyan, R. C. (2011). A case study on the internationalization process of a "born-global" fashion retailer. International Review of Retail, Distribution \& Consumer Research, 21(3), 


\section{3-307. http://dx.doi.org/10.1080/09593969.2011.578804}

Bryman, A., \& Bell, E. (2011). Business research methods. Oxford: Oxford University Press.

Burt, S. L. (2002). International retailing. In P. J., McGoldrick (Ed.), Retail Marketing. Maidenhead: McGraw-Hill.

Cachon, G. P., \& Swinney, R. (2011). The Value of Fast Fashion: Quick Response, Enhanced Design, and $\begin{array}{lllll}\text { Strategic Consumer } \quad \text { Behaviour. } & \text { Management }\end{array}$ http://dx.doi.org/10.1287/mnsc. 1100.1303

Caro, F., Gallien, J., Díaz, M., García, J., Corredoira, J. M., Montes, M., Ramos, J. A., \& Correa, J. (2010). Zara Uses Operations Research to Reengineer Its Global Distribution Process. Interfaces, 40(1), 71-84. http://dx.doi.org/10.1287/inte.1090.0472

Chetty, S., \& Campbell-Hunt, C. (2004). A Strategic Approach to Internationalization: a Traditional Versus a "Born Global" Approach. Journal of International Marketing, 12(1), 57-81. http://dx.doi.org/10.1509/jimk.12.1.57.25651

Crick, D., \& Jones, M. V. (2000). Small high-technology firms and international high-technology markets. Journal of International Marketing, 8(2), 63-85. http://dx.doi.org/10.1509/jimk.8.2.63.19623

Crick, D., \& Spence, M. (2005). The internationalisation of "high performing" UK high-tech SMEs: a study of planned and unplanned strategies. International Business Review, 14(2), 167-185. http://dx.doi.org/10.1016/j.ibusrev.2004.04.007

Cuervo-Cazurra, A., Maloney, M., \& Manrakhan, S. (2007). Causes of the difficulties in internationalization. Journal of International Business Studies, 38, 709-725. http://dx.doi.org/10.1057/palgrave.jibs.8400295

Cyert, R. D., \& March, J. G. (1963). A behavioral theory of the firm. Englewood Cliffs, NJ: Prentice Hall. http://dx.doi.org/10.2307/2091213

Doyle, S. A., Moore, C. M., \& Morgan, L. (2006). Supplier management in fast moving fashion retailing. Journal of Fashion Marketing and Management, 10(3), 272-281. http://dx.doi.org/10.1108/13612020610679268

Dunning, J. H. (1981). International Production and the Multinational Enterprise. London: Allen \&Unwin. http://dx.doi.org/10.2307/2232466

Dunning, J. H. (1988). The Eclectic Paradigm of International Production: A Restatement and Some Possible Extensions. Journal of International Business 1-31.http://dx.doi.org/10.1057/palgrave.jibs. 8490372

Dunning, J. H. (2000). The eclectic paradigm as an envelope for economic and business theories of MNE activity. International Business Review, 9, 163-199. http://dx.doi.org/10.1016/s0969-5931(99)00035-9

European Monitoring Centre on Change (EMCC) Case Studies. (2004). Industrial change in the textiles and leather sector: Hennes \& Mauritz. European Foundation for the Improvement of Living and Working Conditions.

Evans, J., \& Mavondo, F. T. (2002). Psychic distance and organizational performance: An empirical examination of international retailing operations. Journal of International Business Studies, 33(3), 515-532. http://dx.doi.org/10.1057/palgrave.jibs. 8491029

Fernie, J., \& Perry, P. (2011). The International Fashion Retail Supply Chain. In J., Zentes, B., Swoboda\& D., Morschett, (Eds.), Case Studies in International Management (pp. 279-298). http://dx.doi.org/10.1007/978-3-8349-6793-0_16

Fernie, J., Hahn, B., Gerhard, U., Pioch, E., \& Arnold, S. (2006). The Impact of Wal-Mart's Entry into The German and UK Grocery Markets. Agribusiness, 22(2), 247-266. http://dx.doi.org/10.1002/agr.20083

Franks, J. (2000). Supply chain innovation. Work Study, 49(4), 152-155. http://dx.doi.org/10.1108/00438020010330484

Gabrielsson, M., \& Alobaidi, Z. (2004). Pricing strategies of born global. In F., McDonald, M., Mayer \& T., Buck (Eds.), The process of internationalization (pp. 232-252). New York: Palgrave Macmillan.

Ghemawat, P., \& Nueno, J. L. (2006). Zara: Fast Fashion. Boston: Harvard Business School Press.

Govindarajan, V., \& Gupta, A. (2001). The Quest for Global Dominance. San Francisco: Jossey-Bass. 
Guercini, S., \& Runfola, A. (2004). Sourcing Strategies in Clothing Retail Firms: Product Complexity versus Overseas Supply Chain. Journal of Customer Behaviour, 3(3), 305-334. http://dx.doi.org/10.1362/147539204323366417

H\&M. (1996a-2011a). Annual Report H\&M. Stockholm, Sweden: Hennes \& Mauritz AB.

H\&M. (2006b). First Two H\&M Stores Open in Dubai. Retrieved from http://about.hm.com/content/hm/NewsroomSection/en/NewsRoom/NewsroomDetails/229539.html

H\&M. (2012a). Our history. $\quad$ Retrieved from http://about.hm.com/content/hm/AboutSection/en/About/Facts-About-HM/People-and-History/Our-History. html

H\&M. (2012b). Europe, Asia, Middle East \& Northern Arica, and North America. Retrieved from $\mathrm{http} / /$ about.hm.com/content/hm/AboutSection/en/About/Facts-About-HM/About-HM/Sales-Markets/Europ e.html

H\&M. (2012c). Global expansion. http://about.hm.com/content/hm/AboutSection/en/About/Facts-About-HM/About-HM/Expansion-Strategy. html

Hair, J. F., Babin, B., Money, A. H., \& Samouel, P. (2003). Essentials of Business Research Methods. New York: John Wiley.

Hedlund, G., \& Kverneland, A. (1985). Are strategies for foreign market entry changing? The case of Swedish investments in Japan. International Studies of Management and Organization, 15(2), 41-59.

Helfferich, E., Hinfelaar, M., \& Kasper, H. (1997). Towards a clear terminology on international retailing. International Review of Retail, Distribution \& Consumer Research, 7(3), 287-307. http://dx.doi.org/10.1080/095939697343030

Hofstede, G. (1991). Cultures and Organizations: Software of the Mind. London: McGraw-Hill, CA: Sage Publications. http://dx.doi.org/10.2307/2393257

ICFAI Centre for Management Research. (2008). H\&M's Supply Chain Management Practices. ICMR Case Collection.

Inditex. (1998a-2011a). Inditex Annual Report 1998-2011. A Coruña, Spain: Inditex S.A. Retrieved from $\mathrm{http} / / / \mathrm{www}$. inditex.com/en/shareholders_and_investors/investor_relations/annual_reports/

Inditex. (2005). Inditex raises to $100 \%$ its stake in Zara Japan. Retrieved from $\mathrm{http}: / / \mathrm{www}$. inditex.com/en/press/press_releases/extend/00000439

Inditex. (2006a). Inditex acquires the full share capital in its Italian subsidiaries. Retrieved from $\mathrm{http}: / / \mathrm{www} . \mathrm{inditex.com/en/press/press \_ releases/extend/00000540}$

Inditex. (2006b). Inditex has reached an agreement to raise its stake in Zara Deutschland to $78 \%$. Retrieved from http://www.inditex.com/en/press/press_releases/extend/00000462

Inditex. (2006c). Inditex reaches an agreement to acquire Zara's franchise in Russia.Retrieved from $\mathrm{http}: / / \mathrm{www}$. inditex.com/en/press/press_releases/extend/00000447

Inditex. (2008). Zara opens its first stores in South Korea. Retrieved from $\mathrm{http} / / / \mathrm{www}$. inditex.com/en/press/press_releases/extend/00000615

Inditex. (2010). Inditex's international expansion reaches a new milestone with the launch of the first Zara store in India. Retrieved from http://www.inditex.com/en/press/press_releases/extend/00000788

Inditex. (2012a). Inditex Press Kit. A Coruña, Spain: Inditex S.A. Retrieved from $\mathrm{http} / / / \mathrm{www}$. inditex.com/en/press/information/press_kit

Inditex. (2012b). Zara Opens Its New Global Concept Store on New York City's Fifth Avenue. Spain: Inditex S.A. Retrieved from http://www.inditex.com/en/shareholders_and_investors/investor_relations/press_releases/extend/00000910

Johanson, J., \& Vahlne, J. E. (1977). The Internationalization Process of the Firm-A Model of Knowledge Development and Increasing Foreign Market Commitments. Journal of International Business Studies, 8(1), 23-32. http://dx.doi.org/10.1057/palgrave.jibs. 8490676

Johanson, J., \& Vahlne, J. E. (1990). The mechanism of internationalization. International Marketing Review, 
7(4), 11-24. http://dx.doi.org/10.1007/978-0-585-27290-0_2

Johanson, J., \& Vahlne, J. E. (2009). The Uppsala internationalization process model revisited: From liability of foreignness to liability of outsidership. Journal of International Business Studies, 40(9), 1411-1431. http://dx.doi.org/10.1057/jibs.2009.24

Johanson, J., \& Widersheim-Paul, F. (1975). The Internationalization of the firm: Four Swedish cases.Journal of Management Studies, 12(3), 305-322. http://dx.doi.org/10.1111/j.1467-6486.1975.tb00514.x

Jones, M. V., \& Dimitratos, P. (2004). Emerging Paradigms in International Entrepreneurship. Cheltenham, UK: Edward Elgar Publisher. http://dx.doi.org/10.4337/9781845420635

Jonsson, A. (2008). A transnational perspective on knowledge sharing: Lessons learned from IKEA's entry into Russia, China, and Japan. The International Review of Retail, Distribution, and Consumer Research, 18(1), 17-44. http://dx.doi.org/10.1080/09593960701778044

Kim, W. C., \& Hwang, P. (1992). Global strategy and multinational's entry mode choice. Journal of International Business Studies, 25(3), 513-535. http://dx.doi.org/10.1057/palgrave.jibs.8490258

Kling, K., \& Goteman, I. (2003). IKEA CEO Anders Dahlvig on international growth and IKEA's unique corporate culture and brand identity. Academy of Management Executive, 17(1), 31-45. http://dx.doi.org/10.5465/ame.2003.9474809

Knight, G. A., \& Cavusgil, S. T. (1996). The born global firm: A challenge to traditional internationalization theory.Advances in International Marketing, 8, 11-26.

Kogut, B., \& Zander, U. (1992). Knowledge of the firm, combinative capabilities, and the replication of technology. Organization Science, 3(3), 383-397. http://dx.doi.org/10.1287/orsc.3.3.383

Li, L., Li, D., \& Dalgic, T. (2004). Internationalization Process of Small and Medium-sized Enterprises: Toward a Hybrid Model of Experiential Learning and Planning. Management International Review, 44(1), 93-116.

Loane, S., Bell, J., \& McNaughton, R. (2007). A cross-national study on the impact of management teams on the rapid internationalization of small firms. Journal of World Business, 42(4), 489-504. http://dx.doi.org/10.1016/j.jwb.2007.06.009

Lopez, C., \& Fan, Y. (2009). Internationalization of the Spanish Fashion Brand Zara. Fashion Marketing and Management, 13(2), 279-296. http://dx.doi.org/10.1108/13612020910957770

Madsen, T. K., \& Servais, P. (1997). The internationalization of born globals: An evolutionary perspective. International Business Review, 6(6), 561-583. http://dx.doi.org/10.1016/s0969-5931(97)00032-2

Madsen, T. K., Rasmussen, E., \& Servais, P. (2000). Differences and Similarities between Born Globals and Other Types of Exports. Advances in International Marketing, 10, 247-265. http://dx.doi.org/10.1016/s1474-7979(00)10013-4

Mathews, J., \& Zander, I. (2007). The international entrepreneurial dynamic of accelerated internationalization. Journal of International Business Studies, 38(3), 387-403. http://dx.doi.org/10.1057/palgrave.jibs.8400271

McDougall, P. P., Shane, S., \& Oviatt, B. M. (1994). Explaining the formation of international new ventures: The limits of theories from international business research. Journal of Business Venturing, 9(6), 469-487. http://dx.doi.org/10.1016/0883-9026(94)90017-5

Meyer, K. E., Wright, M., \& Pruthi, S. (2009). Managing Knowledge in Foreign Entry Strategies: A Resource-Based Analysis. Strategic Management Journal, 30(5), 557-574. http://dx.doi.org/10.1002/smj.756

Mezias, J. M. (2002). Identifying liabilities of foreignness and strategies to minimize their effects: the case of labour lawsuit judgments in the United States. Strategic Management Journal, 23(3), 229-244. http://dx.doi.org/10.1002/smj.220

Nadkarni, S., \& Perez, P. (2007). Prior conditions and early international commitment : The Mediating Role of Domestic Mindset. Journal of International Business Studies, 38(1), 160-176. http://dx.doi.org/10.1057/palgrave.jibs. 8400248

Nonaka, I. (1994). A dynamic theory of organizational knowledge creation. Organization Science, 5(1), 14-37. http://dx.doi.org/10.1287/orsc.5.1.14

O’Grady, S., \& Lane, H. (1996). The psychic distance paradox. Journal of International Business Studies, 27(2), 309-333. http://dx.doi.org/10.1057/palgrave.jibs. 8490137 
Oviatt, B. M., \& McDougall, P. P. (1994). Toward a theory of international new ventures. Journal of International Business Studies, 25(1), 45-64. http://dx.doi.org/10.1057/palgrave.jibs. 8490193

Oviatt, B. M., \& McDougall, P. P. (1995). Global Start-Ups: Entrepreneurs on a Worldwide Stage. Academy of Management Executive, 9(2), 30-44. http://dx.doi.org/10.5465/ame.1995.9506273269

Oviatt, B. M., \& McDougall, P. P. (2000). International Entrepreneurship: The Intersection of Two Research Paths. Academy of Management Journal, 43(5), 902-906. http://dx.doi.org/10.2307/1556418

Rennie, M. (1993). Global competitiveness: Born global. McKinsey Quarterly, 4, 45-52.

Rothaermel, F. T., Kotha, S., \& Steensma, H. K. (2006). International Market Entry by U.S. Internet Firms: An Empirical Analysis of Country Risk, National Culture, and Market Size. Journal of Management, 32(1), 56-82. http://dx.doi.org/10.1177/0149206305277793

Runyan, R. C. (2003). A resource-based view of internationalization. In J. A., Evans, (Ed.), Retailing 2003: Strategic planning in uncertain times (pp. 174-180). Hempstead, NY: Academy of Marketing Science.

Sapienza, H., Aution, E., George, G., \& Zahra, S. (2006). A capabilities perspective on the effects of early internationalization on firm survival and growth. Academy of Management Review, 31(4), 914-933. http://dx.doi.org/10.5465/amr.2006.22527465

Saunders, M., Lewis, P., \& Thornhill, A. (2007). Research Methods for Business Students (4th ed.). London: Prentice Hall.

Sternquist, B. (1997). International expansion of US retailers. International Journal of Retail \& Distribution Management, 25(8), 262-268. http://dx.doi.org/10.1108/09590559710178347

Sternquist, B. (1998). International Retailing. New York: Fairchild.

Taplin, I. M. (1999). Statistical Review: Continuity and change in the US apparel industry: A statistical profile. Journal of Fashion Marketing and Management, 3(4), 360-368. http://dx.doi.org/10.1108/eb022572

Taplin, I. M. (2006). Restructuring and reconfiguration: the EU textile and clothing industry adapts to change, European Business Review, 18(3), 172-186. http://dx.doi.org/10.1108/09555340610663719

Taylor, S. J., \& Bogdan, R. (1998). Introduction to Qualitative Research Methods (3rd ed.). New York: John Wiley.

The Gap. (2011). The Gap Inc. 2011 Annual Report, San Francisco: The Gap Inc. Retrieved from $\mathrm{http}$ //investors.gapinc.com/phoenix.zhtml? $\mathrm{c}=111302 \& \mathrm{p}=$ irol-reportsAnnual

Ticehurst, G. W., \& Veal, A. J. (2000). Business Research Methods: A Managerial Approach. New South Wales, Australia: Pearson Education Pty Ltd.

Tokatli, N. (2008). Global Sourcing: Insights from the Global Clothing Industry-the Case of Zara, a Fast Fashion Retailer. Journal of Economic Geography, 8, 21-38. http://dx.doi.org/10.1093/jeg/lbm035

Wernerfelt, B. (1984). The resource-based view of the firm. Strategic Management Journal, 5(2), 171-180. http://dx.doi.org/10.1002/smj.4250050207

Yin, R. K. (2009). Case Study Research: Design and Methods (4th ed.). California, US: SAGE Publications.

Zahra, S. A., Ireland, R. D., \& Hitt, M. A. (2000). International Expansion by New Venture Firms: International Diversity, Mode of Market Entry, Technological Learning, and Performance. Academy of Management Journal, 43(5), 925-950. http://dx.doi.org/10.2307/155642

\section{Copyrights}

Copyright for this article is retained by the author(s), with first publication rights granted to the journal.

This is an open-access article distributed under the terms and conditions of the Creative Commons Attribution license (http://creativecommons.org/licenses/by/3.0/). 